LIV.-Descriptions of new Species of Madrepora in the Collection of the British Museum. By George Brook, F.L.S.

DuRING the examination of the collection of Madrepores in the British Museum I have found a number of specimens which, after careful comparison with types contained in other European Museums, seem to me to be undescribed. In anticipation of a fuller detailed account of the species of this family, I offer the following abridged descriptions of the new species.

\title{
Madrepora Brueggemanni.
}

Madrepora laxa, Brüggemann (non Lamarck), Abh. naturw. Ver. Bremen, Bd. v. 1877 , p. 544.

Corallum spreading, arborescent, laxly branched. Main branches stout, 2 to 3 centim. thick, elongate or short and obtuse. Elongate branches 15 centim. long and 1.5 centim. thick, little divided, scarcely tapering, except near the apex; stunted form of similar diameter, more frequently and divaricately divided; ultimate divisions 2 to 3 centim. long, 1 to 1.5 centim. thick, searcely tapering, very obtuse at the apex. A few short conical buds or abortive branchlets are scattered at intervals from the base upwards. Corallum rather dense, surface strongly echinulate. Apical corallites very variable in size, sometimes 4 to 6 millim. in diameter, with very thick wall, not exsert or only slightly so; at others conical, 2 millim. exsert, 4 to 5 millim. diameter at the base and about 3 millim. at the apex. In certain cases, where the terminal divisions are very stout, a single apical corallite does not occur, but, instead, the apex is occupied by several stout cylindrical corallites, with only the rounded margin prominent. This clearly is an approach to the condition in the subgenus Isopora. Lateral corallites crowded, very unequal and irregular on the upper surface, but distant below; short, thick, spreading, tubular, with small aperture and rounded margin, 2 to 2.5 millim. diameter and 2 to 5 millim. long, but most are short. At intervals certain corallites become more elongate and thickened and form buds. The inner part of the wall is often not so thick and prominent, in which case the aperture opens inwards, and the outer part of the wall may project in a point or hooked knob some distance above it. This type of corallite is most frequent in certain elongate 
branched specimens which probably constitute a distinct variety. Star well developed, primary septa broad and subequal, the others not so prominent; wall finely and closely granular, echinulate, the echinulate plates often arranged in rows at the base of the corallites. Immersed corallites are not numerous, and occur only on the under surface of the branches.

Indo-Pacific Ocean; Singapore; N.E. Australia.

\section{Madrepora clathrata.}

Corallum fan-shaped, reticulate, 30 centim. high, breadth across the upper part 33 centim., but becoming rapidly narrower below. A main stem is absent and the branches in the lower part have a diameter of about 1 centim.; their subdivisions are at first only slightly spreading, but become more divaricate above. The branchlets are numerous, 2 to 4 centim. long and 5 millim. thick, frequently arched and laid across one another at various angles, the whole fused together into an irregular network, the meshes of which vary from 4 to 12 millim. across. Apical corallites 2 millim. diameter, 1 to 2 millim. exsert, wall rather thick and cylindrical, with a flat or slightly rounded apex; the star consists of six subequal septa of moderate development. Lateral corallites on the anterior (superior?) surface very unequal, not very crowded; the larger ones tubular, at right angles, with an oblique aperture, from 3 to 4 millim. long and about 2 millim. diameter, but frequently a little compressed; a few are longer and proliferous, the remainder are less spreading, shorter, tubular, tubo-nariform, and nariform to subimmersed; the only truly immersed corallites on the upper surface occur in the lines of fusion. Star imperfect, the directive septa moderately developed, but the others are rudimentary or wanting. The lateral corallites on the posterior (inferior?) surface are distant, very short, chiefly subimmersed or cochleariform. Corallum very porous, surface closely reticulate and echinulate, the echinulations often plate-like. Wall of the apical corallites and of the elongate lateral ones costate above, the costæ being echinulate below; wall of the remaining lateral corallites echinulate in rows.

Indian Ocean; Mauritius.

\section{Madrepora complanata.}

Corallum flabellate, probably about 23 centim. high and 40 centim. broad. The main stem gives off alternate branches 
at an acute angle which may be 20 centim. long and 1.5 centim. thick, spreading out laterally, their subdivisions subalternate and confluent, the whole habit recalling the espalier form of fruit-tree; a few very short branchlets arise obliquely from the anterior surface, but the majority conform to the general plane of growth. Apical corallites 2 to 2.5 millim. diameter, tubular, scarcely exsert, wall not specially thickened, and closely resembling the lateral ones except in shape. Lateral corallites on the anterior surface subequal, very spreading, boat-shaped, nariform, or labellate, the aperture wide and elongate, the upper margin almost at right angles to the branch, the lower more or less convex; wall thickened, apex often a little hooked; 2.5 millim. long and about 2 millim. thick. The corallites become a little less prominent towards the base of the corallum, but immersed corallites are practically absent. On the inferior surface the corallites are more scattered and irregularly arranged, many open downwards, the majority are appressed, tubular, with only the outer part of the wall free. A few immersed corallites occur, but they are neither numerous nor generally distributed. Corallum moderately porous, reticulate in section, anterior surface subreticulate and echinulate, posterior surface dense and finely echinulate, wall finely striate and echinulate. The lateral corallites have six very narrow equal septa, with occasionally indications of a second series.

Indian Ocean; Seychelles.

\section{Madrepora concinna.}

Corallum corymbose, 30 centim. broad and 12 centim. high, from a central base, scarcely pedicellate. Under surface of the branches horizontal, much flattened, more or less confluent, 9 centim. long and 2 centim. broad, provided with irregular verruciform and lateral, elongate, tubular or conical corallites; immersed ones almost absent. Branches on the upper surface 5 to 6 centim. long, 8 to 13 millim. thick, very proliferous. Apical corallites 3.5 millim. diameter at the base, tapering, 3 millim. exsert. Lateral corallites very unequal; those at the apex are very short, small and thinwalled, others immediately below tubo-nariform or tubular, with a round or oblique aperture, frequently opening inwards; some are 3 to 6 millim. long and 2 to 3 millim. in diameter, spreading, but not at right angles, wall thick, margin rounded; others between are shorter or subimmersed; all are short or subimmersed at the base of the branches. Star not prominent, consisting of narrow directive septa and four others which are 
rudimentary. Corallum dense, surface and wall finely echinulate.

Mauritius.

\section{Madrepora delicatula.}

Corallum extending horizontally, branches not over 8 millim. thick, laxly coalescent, but not complanate, and bearing on the under surface numerous slender branchlets almost at right angles, 1 centim. or more in length and generally 2.5 millim. diameter at the base, with distant appressed tubular buds. Appressed tubular and immersed corallites also occur between the twigs. The upper surface bears slender arcuate branches not over 5 millim. thick, which give rise to delicate ascending branchlets singly or in groups of two or three; these are 1.5 to 2.5 centim. long and scarcely 3 millim. thick at the base, apparently tapering, owing to the lateral corallites being shorter near the apex. Apical corallites 1.5 millim. diameter, usually 2.5 millim. exsert. Lateral corallites rather distant, round-nariform, or labellate, 1 to $1 \cdot 3$ millim. wide and 1 to 4 millim. long; the lip of the more elongate ones is frequently a little incurved ; wall thin, aperture round, star indistinct. Corallum very porous and fragile, surface vermiculato-echinulate, wall finely striate, echinulate near the base.

Solomon Islands (Dr. Guppy).

\section{Madrepora diversa.}

Corallum cespitose from a broad incrusting base, 10 centim. high and 18 centim. broad. Branches 4.5 centim. long, 1.3 to 1.8 centim. thick, simple or divided into two to five little spreading digitiform branchlets about 2.5 centim. long and 1 centim. thick, obtuse at the apex. Apical corallites 3.5 to 4 millim. broad, scarcely exsert. Lateral corallites chiefly tubular, with a more or less oblique aperture, very unequal in length and diameter, all are ascending. The larger ones are 3 to 6 millim. long and 2 to $2 \cdot \tilde{5}$ millim. diameter, slightly compressed; wall thick, but only slightly rounded at the margin; smaller nariform and subimmersed corallites occur between the others quite to the apex; a few are proliferous and 5 to 8 millim. in length. About 2 centim. below the apex the prominent corallites are nariform or tubonariform, with a thick and strongly convex outer wall; at the base nearly all are immersed. Star indistinct, often only the directive septa are recognizable. Corallum moderately Ann. \& Mag. N. Hist. Ser. 6. Vol. viii. 
porous, surface strongly echinulate, wall finely striatoechinulate.

\section{Diego Garcia (G. C. Bourne, Esq.).}

Madrepora (Isopora) hispida.

Madrepora securis, Quelch (non Dana), 'Challenger' Reef-Corals, p. 148.

Corallum similar to that of $I$. palifera *, Lamk., consisting of thick plates 4 to 8 centim. broad and 2 to $3 \cdot 5$ centim. thick, or, in other cases, of elongate, thick, rounded branches 3 to 6 centim. diameter near the base and rarely under 3 centim. near the apex. Apices usually flattened. Corallites at the apex 2.5 to 3 millim. diameter, with smaller ones scattered amongst. Walls confluent, as in 1. palifera. Lateral corallites usually crowded, but sometimes rather distant, short, nariform, or tubo-nariform, but the inner wall always short and thin. Diameter 1.5 millim., length 2 millim. The wall and surface of the cœnenchyma consist of radiating spinose plates, giving a very hispid appearance. Septa in two cycles, the directives broad, other primaries narrow, remainder sudimentary.

Differs from $I$. palifera, Lamk., in the smaller size of the corallites and the hispid character of the surface.

Pacific Ocean; Philippines; Banda; Ponapé.

\section{Madrepora inermis.}

Corallum consisting of slender, laxly-divided branches, which probably extend sub-horizontally. The branches are about 21 centim. long and 8 millim. thick, somewhat flattened in places, and completely or almost completely devoid of corallites on the under surface, forked and divaricately branched; the branchlets are sublateral, 1.5 to 6 centim. long, 4 to 5 millim. thick, scarcely tapering; those under 5 centim. in length are usually simple. In addition to the more noticeable branchlets there are a few short lateral subalternate ramiculi on the stouter branches at intervals of about 1 centim.; they are 4 to 8 millim. long and 3 millim. thick. Apical corallites 2 millim. diameter, 1 millim. exsert, wall scarcely thickened; star of six septa very well developed, with sometimes traces of a second cycle. Lateral corallites very short, spreading, tubular, rather distant; length 1 to 2 millim., diameter the same, but usually 1.5 millim., and the base may be dilated; those near the apex of a branchlet are not so spreading, but the aperture is always rounded; the longest ones are lateral in position, and on becoming prolife-

* I find that Astraa palifera, Lamk., is Dana's Madrepora labrosa, and the name has priority. 
rous give rise to the short ramiculi already referred to. Immersed corallites are practically absent. Wall thin but firm, star of six septa more or less fully developed, the lower directive often much broader than the others. Corallum very dense; surface dense, smooth, and almost void of corallites on the underside, slightly rough, but not spinose on the anterior surface of the stouter branches. The wall of the apical and younger lateral corallites is roughly costulate, and the striations are continued on to the cœenenchyma, but below the striations are lost on the corallites as well as on the general surface.

South Seas.

\section{Madrepora intermedia.}

Corallum arborescent, similar to that of $M$. brachiata in habit. Main branches 2 to 2.5 centim. thick and 25 centim. long, moderately subdivided, especially near the apex; ultimate divisions 3 to 6 centim. long and 1 centim. or more thick, gradually tapering to a blunt apex or more rapidly tapering and pointed. Apical corallites 2.5 millim. diameter, 0.5 to 2 millim. exsert, but usually short; aperture large, frequently oval; primary septa well developed, secondary series not prominent. Lateral corallites tubular, spreading, very variable in length and also in diameter. The majority extend almost at right angles to the branch, excepting near the apex, and have a more or less oblique aperture; they are about 3 millim. long and 2 millim. diameter; wall firm, but not thickened. Numerous short tubular to subimmersed corallites occur between the others, varying from 1 to 1.5 millim. in diameter. The corallites become short and thickened, wart-like on the main branches, whilst on the under surface the majority are immersed. Primary septa all narrow, but the directives are the more prominent, and in the older parts of the corallum may be broad. Corallum very porous, surface reticulate and echinulate; wall striato-echinulate, becoming later echinulate in linear series.

Maldive Islands.

\section{Madrepora leptocyathus.}

Corallum flattened, vasiform from a broad base, not pedicellate. Marginal branches oblique, fused into a solid plate below, excepting near the periphery, where they are a little flattened and covered with short, crowded, appressed, tubular corallites with thin wall. On the upper surface all the branchlets rise from a solid base with very numerous immersed corallites. The branchlets are about 3 centim. long 
and 1 to 1.4 centim. thick, frequently angular below, but more tapering above; the apices are usually 1.7 centim. apart. Those in the centre are chiefly simple, but may bear a few proliferous corallites; others, particularly near the margin, are divided. Apical corallites 2.5 to 3 millim. diameter, cylindrical, scarcely exsert. Lateral corallites small, crowded, tubular or tubo-labellate, spreading at right angles, wall thin and porous; they are $1 \cdot 5$, rarely 2 , millim. diameter, and seldom over 2.5 millim. long, a little unequal, with small and delicate ones between. On the lower part of the branchlets the prominent corallites are not so numerous and the wall is thickened. Proliferous corallites 5 millim. long and 4 millim. wide (including the lateral buds). Star usually indistinct, but the directive septa are sometimes prominent. Corallum rather dense, surface finely reticulate and echinulate, wall striato-echinulate.

The type specimen appears to consist of two circular colonies fused together.

Samoa.

\section{Madrepora macrostoma.}

Corallum subeorymbose or umbellate, 33 centim. broad and 15 centim. high, consisting of crowded erect branches springing from an obconical fastigiate cluster of dead coral. Branches 4 centim. long, simple or consisting of two or three subparallel divisions about 1 centim. thick, scarcely tapering. Apices a little over 1 centim. apart. Apical corallites 2.5 to 3 millim. thick and 1 millim. exsert. Lateral corallites broad, round, and ascending, tubo-labellate above, 3 millim. long and 2 to 2.5 millim. diameter; aperture large and circular, wall very thin. Star well developed but deep, consisting of twelve prominent septa; lower down the corallites become thickened, verruciform, or immersed. Corallum very porous and reticulate in section, surface openly reticulate, wall striato-reticulate, echinulate near the base.

Mauritius.

\section{Madrepora ornata.}

Corallum stout, arborescent, branches elongate, below laxly divided, 2 to 3 centim. thick, often oval in section, divided into a cluster of branches at the apex, the whole densely covered with short ramiculi 8 to 13 millim. long and 5 to 7 millim. thick, and about 1 centim. apart, with numerous very short or immersed corallites between. Apical corallites 3 millim. diameter, 1 to 1.5 millim. exsert; wall thick, margin ruonded, aperture about 1 millim. Lateral corallites short, round, nariform, with thickened wall and rounded margin, 
outer wall a little convex, 1.5 to 2.5 millim. long and nearly 2 millim. diameter. On the stouter ramiculi two or three corallites become 3 millim. long and bear three or four buds. The ramiculi are as numerous on the inferior (posterior) surface of the branches as elsewhere, but are usually shorter. Star usually indistinct, but one or both directive septa moderately prominent. Corallum moderately porous, surface spongy, echinulate; wall striato-reticulate and echinulate.

The species is allied to M. gravida, Dana.

Darnley Island (J. B. Jukes).

\section{Madrepora pacifica.}

? Madrepora robusta, Bassett-Smith (non Dana), Ann. \& Mag. Nat. Hist. vol. vi. 1890 , p. 452.

Corallum subarborescent, stout, spreading obliquely, resembling that of $M$. nobilis in habit. Branchlets 6 to 15 centim. long and 2 to 3 centim. thick, simple or subsimple, tapering slightly to a blunt apex, or the distal half more rapidly tapering: and pointed. A pical corallites 2.5 millim. diameter or a little over, 2 miilim. exsert. Lateral corallites very much crowded, about half are elongate, tubular, half-tubular, or dimidiate, the remainder short, labellate, subimmersed, or immersed. The prominent corallites are about 1.5 millim. in diameter and 3 to 4 millim. long, spreading nearly at right angles, often a little recurved; wall firm but relatively thin, delicately striate without echinulations. Primary cycle of septa not prominent, the directives most noticeable; in many of the immersed corallites they alone can be made out. Corallum very dense, surface spongy echinulate; in many parts the corallites are so crowded that little or no cœenenchyma occurs between them.

A specimen referred by Bassett-Smith to M. robusta appears to belong to this species, but the branches are not so stout as in the type, and the corallum appears to form an incrustation over dead pieces of coral.

Pacific Ocean; Samoa Islands; China Sea.

\section{Madrepora (Isopora) plicata.}

Corallum consisting of broad oblique plates from a common base. The plates are about 8 centim. long and 4 to 9 centim. broad near the apex, narrower below and 1 centim. thick. Each plate bears one or more prominent longitudinal ridges on its surface. Each ridge bears a number of rosettes of corallites, the centre corallite in each being rather larger than the others, thus indicating an approach to branch formation with its accompanying enlarged terminal (parent) corallite. Corallites at the apices of the plates tubular, 2 millim. in 
diameter, slightly prominent, wall thick and porous. Lateral corallites tubular and appressed above, shorter and more spreading near the base. Length 1 to 4 millim., diameter 1 to 1.5 millim. Aperture large; wall thin compared with other species of the subgenus. Surface finely clothed with longitudinal series of dentate plates.

The species differs from all others of the subgenus in the possession of thin-walled lateral corallites.

Tongatabu (J. J. Lister, Esq.).

\section{Madrepora polymorpha.}

Madrepora abrotanoides, Dana (non Lamarck), Zoophytes, p. 477, pl. xli. fig. 1; Verrill, Bull. Mus. Comp. Zcol. vol. i. 1864, p. 41; Rathbun, Proc. U.S. Nat. Mus. vol. x. 1887, p. 12.

Corallum fruticose, spreading, ramose; branches 8 to 20 centim. long, usually about 1.5 to 2 centim. thick, gradually tapering; the branches bear numerous branchlets, spreading usually at an angle of $80^{\circ}$ to $90^{\circ}$, and varying in importance from thickened and elongate proliferous corallites to subterete and tapering twigs 4 centim. long and 1 centim. thick. A pical corallites 1.5 to 2 millim. diameter and 0.5 to 2 millim. exsert; wall thick or comparatively thin. Lateral corallites compressed, nariform, or tubo-nariform, unequal, the longer ones becoming tubular and proliferous; some distance below the apex all become verruciform, with a dilated wall, which gradually becomes reduced to a ring-shaped fold. Immersed corallites are usually wanting, even in the older parts of a colony; but in one or two specimens which agree closely in other respects immersed corallites may take the place of those with a ring-shaped lip. Lateral corallites 1.5 millim. diameter or under and 1.5 to 3 millim. or more in length ; aperture oval, wall varying in thickness in different specimens; always thickened some distance below the apex of a branch, and in some cases quite to the apex; in the latter case the wall of the apical corallite is also thickened. The apical corallites are provided with twelve septa, none of which are very prominent; those of the lateral corallites are also usually narrow, including the directives; in the corallites situated some distance from the apex the second cycle is almost as well developed as the first. Corallum dense, even near the apex of a branch in most specimens; surface and wall finely and closely echinulate.

Indo-Pacific Ocean; Malacca; Fiji?

\section{Madrepora polystoma.}

Corallum corymbose and complanate below, 35 centim. wide and 12 centim. high, closely resembling that of $M$. con- 


\section{Madrepora in the British Museum.}

cinna in habit. Branches complanate below, the basal parts fused into a solid plate with immersed corallites; distal parts with hemicotyloid corallites and a few lateral, tubular or conical ones. Branches on the upper surface about 4 centim. long and 1.3 to 1.5 centim. thick, angular below, with crowded immersed corallites; often divided above into two to four branchlets, many of which, especially near the centre of the corallum, bear numerous ascending proliferations. Apical corallites 2.5 to 3 millim. diameter, rarely over 1 millim. exsert, margin scarcely rounded. The central branchlets bear crowded proliferations, 7 millim. long and 4 millim. thick, with crowded immersed corallites between ; others are dimidiate and appressed, 2.5 to 4 millim. long and 1.5 millim. thick; wall thin but firm. The peripheral branchlets have few proliferous corallites; most are subequal, nariform, with an elongate lip, and a little compressed, 3 millim. long and 1.3 millim. thick. Star moderately prominent, the directive septa very broad. Corallum rather porous, surface tinely echinulate, wall striato-echinulate.

Mauritius.

\section{Madrepora procumbens.}

Corallum prostrate or subprostrate, subdivisions free. Branches up to 16 centim. long and 1 centim. thick, bearing ramiculi 1.3 to 3.5 centim. long, each of which is usually produced from a single tubular corallite by the formation of lateral corallites upon it, nariform or tubo-nariform at first, but becoming spreading tubular, 4 to 9 millim. long. There may be twenty or more on a twig 3 centim. long, radiating in all directions, the longer ones arched and bearing very short nariform buds. The stem and main branches bear a few corallites at irregular intervals, nariform or subimmersed and immersed. The elongate tubular corallites are 2 millim. diameter near the base and 1.5 at the apex. Apex suddenly contracted; aperture small, enclosing a star of six welldeveloped septa. Corallum dense, surface finely echinulate, not pitted, wall echinulate in rows.

This species comes near to $M$. longicyathus, and may prove to be only a well-marked variety of it. It differs, however, in habit and in the arrangement and number of the corallites on the branchlets; the axial corallite also usually bears buds to within 2 millim. of the apex, whereas in M. longicyathus the terminal 7 millim. is usually free. In one specimen the branches extend horizontally, in another obliquely.

South Seas. 


\section{Madrepora pulchra.}

Madrepora cribripora, Bassett-Smith (non Dana), Ann. \& Mag. Nat. Hist. vol. vi. 1890, p. 452.

Corallum arborescent, branches 1.2 to 1.8 centim. thick, terete, bearing branchlets or radiating clusters of branchlets at intervals of 2.5 to 5 centim.; branchlets elongate, simple or subsimple, 3.5 to 9 centim. long, 8 to 12 millim. thick, gradually attenuate; the angle of the branchlets varies from $30^{\circ}$ to $90^{\circ}$. A pical corallites 3 millim. diameter, about 2.5 millim. exsert; those of the branchlets rather smaller. Lateral corallites all spreading at right angles, excepting near the apex of a branchlet, all short, tubular, a little variable in length, and exhibiting considerable variation in diameter. Length subimmersed to 1.5 millim., diameter 0.75 to 2 millim. The aperture of the larger corallites is usually a little oblique, and in some cases the inner part of the wall is only slightly developed, whilst the outer is elongate, giving a tubo-labellate form; the inner part of the wall is, however, rarely absent, excepting in the older parts of the corallum, where the majority of the corallites are immersed. The outer part of the wall is usually a little thickened in the larger corallites, but the aperture remains over 1 millim. in diameter. Star of the apical corallites consisting of six welldeveloped subequal septa, the second cycle rudimentary; in the lateral corallites the star is rudimentary, the directives usually recognizable, and sometimes two or, more rarely, four others. Corallum very porous, surface reticulate and echinulate; wall striato-reticulate, echinulate in the case of the stouter corallites.

Keeling Island; Tizard Bank.

\section{Madrepora samoensis.}

Corallum cespitose from a broad, rounded, incrusting base; height of corallum 24 centim., breadth 28 centim. Branches very stout and much divided. The main branches usually become divided into eight or ten secondary ascending branches, which increase in length towards the centre of the corallum; the outer ones are 3 to 5 centim. long, the inner ones 12 or 13 centim.; these branches are often 2 centim. thick, not terete, but, owing to crowding, they are more or less angular in section; the secondary branches bear a third series of ascending branchlets 2 to 6 centim. long and 1 centim. thick, those directed outwards being longest and most numerous. All the divisions are only slightly tapering and have a blunt apex. Apical corallites 3 millim. diameter or less in the case of the smaller subdivisions, scarcely exsert; wall thick, very porous, margin rounded. Star very distinct, the 
vrimary septa often nearly meet in the middle line, but in the smaller corallites the directives are broadest; a second cycle is also moderately developed. Around the apical corallite the lateral corallites are frequently arranged in subregular longitudinal rows. The lateral corallites are nariform or short-tubular at first, with the inner part of the wall more or less incomplete, the outer part thickened and very porous; they are 2 to 3 millim. long and about 2 millim. diameter. Rows of smaller subinmersed corallites are situated between the prominent ones, but the linear arrangement is lost 3 to 5 centim. from the apex. At a point about 2 centim. from the apex the prominent corallites become more thickened and bear buds; they are then about 4 millim. long and nearly 3 millim. diameter. Such proliferous corallites occur at intervals of 5 to 8 millim. over the whole of the upper part of the corallum; a few become more elongate and may attain a length of 2 centim. At a point varying from $2 \cdot 5$ to 6 centim. from the apex of a branch or branchlet the whole of the corallites become short, and on the inner sides of the branches almost all of them are immersed. The star of the lateral corallites not destined to form proliferations is quite indistinct, usually only the directive septa are recognizable. Corallum very porous; surface spongy reticulate and echinulate, becoming regularly reticulate below; wall striate and fenestrated, margin not rounded.

Samoa Islands (Rev. S. J. Whitmee).

\section{Madrepora spathulata.}

Corallun prostrate, complanate below. Branches 1.5 centim. thick, flattened on the under surface, with numerous immersed and short nariform corallites, and a few spreading tubular ones between; branchlets in the general plane with one or several tubular corallites near the apex, often 5 millim. long and 2 millim. thick. Branches on the upper surface arcuate, 7 centim. long, and usually consisting of two branches fused together, so as to be somewhat oval in section, 1.8 by 1 centim., usually 1 centim. thick up to within 1 centim. of the apex; divided nearer the apex into two to four branchlets, most of which are also imperfectly divided into two; apices blunt. Apical corallites 2 to 2.5 millim. thick, scarcely exsert; wall thick and very porous; aperture usually small, but sometimes funnel-shaped. Lateral corallites crowded, spreading at right angles, 2 millim. broad and long in the upper parts, spathulate, and the rounded lip sometimes recurved; below the wall is not so prominent and a little thickened, and at the base of the branchlets the corallites are all subimmersed or immersed; aperture nearly 1 millim., but 
the cells occurring in lines of fusion are smaller. Star indistinct, only the directive septa recognizable. Corallum very porous, surface reticulate and echinulate; wall fragile, striatoreticulate, and later echinulate.

Treasury Island, Solomon Islands (Dr. Guppy).

\section{Madrepora subglabra.}

P Madrepora echinata, Quelch (non Dana), 'Challenger' Reef-Corals, p. 162.

Corallum extending in elongate, slender, and oblique or subprostrate branches, closely resembling $M$. procumbens in habit and in the form of the branchlets. Branches 6 to 18 centim. long, 7 millim. diameter, not terete, owing to the swollen bases of the branchlets. Branchlets 1 to 4 centim. long, similar to those of $M$. procumbens, but the corallites are more slender, scarcely over 1 millim. diameter at the apex; margin plane, aperture not contracted; they vary from 4 to 15 millim. in length, the majority are about 7 millim. long, the terminal 3 or 4 millim. being free from budding corallites. The main branches bear a very small number of subimmersed corallites about 0.7 millim. diameter. 'The star consists of six septa, the directives being thick and prominent, the others much narrower. Corallum dense, surface almost smooth, excepting near the apex, where it is finely echinulate; wall very finely striato-echinulate at first, the striæ becoming lost later, and subsequently the echinulations as well.

The 'Challenger' specimens referred by Quelch to M. echinata, together with another specimen in the collection, appear to differ from the above in having a slightly more prostrate habit and in the presence of stronger echinulations; but in these the echinulations are much finer and shorter on the inferior surface of the branches.

South Seas; Fiji Reefs.

\section{Madrepora symmetrica.}

Corallum broad, flat, corymbose, with a short central base, scarcely pedicellate, 35 to 52 centim. broad and 12 to 14 centim. high. Under surface complanate, branches crowded and coalescent, somewhat flattened below; branches 1 centim. thick, with numerous much appressed corallites and lateral tubular ones, which give rise to branchlets in the general plane; some are 8 to 10 millim. long, 2 millim. thick, and simple; others bear lateral nariform corallites, others again tubular ones, those near the base being elongate and very spreading; immersed corallites almost absent from the under surface. On the upper surface the main branches give rise 
at intervals to clusters of two to five suberect branchlets, and their distal extremities are arcuate, 3 to 3.5 centim. long, and divided into branchlets, which, like the more central ones, are 2 to 3 centim. long and scarcely 5 millim. thick; apices 6 to 7 millim. apart. Upper surface of the main branches and base of the branchlets provided with numerous large immersed corallites, with an aperture of 1 millim. Apical corallites about 2 millim. diameter, usually about 1 millim. exsert. Lateral corallites ascending, elongate, labellate, and imbricate, 3 to 4 millim. long and 1.5 millim. thick, apices more or less pointed. Corallum very porous and reticulate in section, surface densely echinulate; wall thin, finely striato-reticulate and echinulate, except in the case of the younger ones. Star not recognizable in the prominent corallites; in the immersed ones it consists of six very narrow septa.

Two specimens have the apices of some of the branchlets subdivided; in a third the majority are proliferous and some of the apical corallites rather over 2 millim. in diameter.

Mauritius.

LV.-Contributions towards a General History of the Marine Polyzoa, 1880-91.-Appendix. By the Rev. Thomas Hincks, B.A., F.R.S.

[Continued from p. 176.]

\section{'Annals,' July 1881 (p. 55 sep.). \\ Hiantopora ferox, MacGillivray.}

In a previous paragraph I have pointed out that this form cannot be referred to Cribrilina, from which genus it has been rightly separated by MacGillivray. Since it was written I have seen Mr. Kirkpatrick's Report on the Polyzoa from Torres Straits collected by Professor Haddon *, in which he ranks Hiantopora ferox as a variety of Membranipora radicifera, Hincks. The connexion between these two very dissimilar species he supposes to be established by the discovery of a variety of $M$. radicifera, to which he has given the name intermedia. Granting that the latter is, as $\mathrm{Mr}$. Kirkpatrick supposes, a variety of $M$. radicifera, the further development and fusion of its spinous processes may have originated a form bearing a general resemblance to $H$. ferox. Beyond this, I confess, I am not prepared to go. Mr. Kirkpatrick goes much further; he assumes that

* 'Scientific Proceedings of the Royal Dublin Society,' vol. vi. part 10. 


\section{$2 \mathrm{BHL}$ Biodiversity Heritage Library}

Brook, George. 1891. "LIV.-Descriptions of new species of Madrepora in the collection of the British Museum." The Annals and magazine of natural history; zoology, botany, and geology 8, 458-471.

https://doi.org/10.1080/00222939109459223.

View This Item Online: https://www.biodiversitylibrary.org/item/63425

DOI: https://doi.org/10.1080/00222939109459223

Permalink: https://www.biodiversitylibrary.org/partpdf/59349

\section{Holding Institution}

University of Toronto - Gerstein Science Information Centre

\section{Sponsored by}

University of Toronto

\section{Copyright \& Reuse}

Copyright Status: NOT_IN_COPYRIGHT

This document was created from content at the Biodiversity Heritage Library, the world's largest open access digital library for biodiversity literature and archives. Visit BHL at https://www.biodiversitylibrary.org. 